International Journal of Environment, Agriculture and Biotechnology
Vol-6, Issue-1; Jan-Feb, 2021
Journal Home Page Available: $\underline{\text { https://ijeab.com/ }}$
Journal DOI: $10.22161 /$ ijeab

\title{
Why is China's the Belt One Road Initiative successful? Lessons from the Cooperation with the Five Central Asia Countries
}

\section{Sicheng Meng}

Central University of Finance and Economics, School of International Economics and Trade, 39 South College Road, Haidian, District,Beijing, P.R.China

Received: 22 Oct 2020; Received in revised form: 29 Dec 2020; Accepted: 28 Jan 2021; Available online: 16 Feb 2021

(C2021 The Author(s). Published by Infogain Publication. This is an open access article under the CC BY license

(https://creativecommons.org/licenses/by/4.0/).

\begin{abstract}
This paper investigates Why is China can gain great success in capacity cooperation with the countries involving in the Belt One Road Initiative. This paper uses the cooperation with the five Central Asian countries, Kazakhstan, Kyrgyzstan, Tajikistan, Turkmenistan and Uzbekistan, as examples to find out the potential factors. Through analyzing the complementarity of long-term strategies of these five countries and China, and the supplementary policies for countries involving in Belt One Road Initiative, this paper finds that cost-effective technologies and excellent skills in infrastructure construction are in line with the needs of the five countries in their long-term development plans. Combining with supplementary policies like the 'five connectivity' and support from international institutions like AIIB and ADB, the benefit and security of the two groups China and countries involving in Belt One Road Initiative are highly guaranteed. Moreover, China has no tendency in geopolitical target in those areas and after all projects are finished, cooperation through public-private partnership can eliminate the concern about being control by China in infrastructure and energy sectors.
\end{abstract}

Keywords - Capacity cooperation, the Belt One Road Initiative, Strategy complementarity, Country safety and international cooperation.

\section{INTRODUCTION}

Since the Belt and Road initiative was put forward in 2013, more than 100 countries and international organizations around the world have actively responded to support this initiative. Over the past five years, from top-level design to pragmatic advancement, the Belt and Road development has covered smoothly from specific locations to regions. Among all the plans and projects, cross-border direct investment is a key area of economic cooperation between China and countries related to the Belt and Road initiative. The Vision and Actions for Promoting the Joint Construction of the Silk Road Economic Belt and the 21st Century Maritime Silk Road issued by China in 2016 and the Belt and Road International Cooperation Summit Conference in 2017 all listed investment cooperation as core topic for the Belt and Road construction. Located in the core area of the Eurasian continent, the five Central Asian countries are the key land 
linkage of the Silk Road Economic Belt. They are also the primary area for China to seek economic cooperation from the vast Eurasian continent. They play an important role in connecting China to Europe and West Asia. It is also regarded as the area with the greatest potential for economic and trade investment in the Silk Road Economic Belt. In early January 2017, China successively celebrated the 25th anniversary of the establishment of diplomatic relations with the five friendly neighbors in Central Asia. In the past 25 years, with the rapid improvement of the economic and trade cooperation environment between China and Central Asian countries, China's direct investment in Central Asian countries has developed rapidly and the scale has continued to expand. For a long time, the five Central Asian countries have formed a resource-export-oriented open economy, and their economic development is highly dependent on foreign countries. The countries' economic growth is overly dependent on the comparative advantage of a single factor formed by their natural resources. Therefore, expanding the attraction of foreign investment is important to promote their national economic development. As the largest developing country, China is in the mid-stage of industrialization and has the dual advantages of high-end technology and labor costs. It has a complete industrial system, and its equipment manufacturing level is at the mid-end of the world's industrial chain. These advantages make it extremely cost-effective as a choice for economic partner. However, the five Central Asian countries have different levels of economic development. For this reason, they all had different domestic investment environments and widespread problems such as insufficient infrastructure construction and industrial investment. With the acceleration of the urbanization process in developing countries, the demand of the improvement of infrastructure and production capacity has become a practical factor to meet the gap between the supply and demand.

Faced with such large national differences, how did China gain the support of countries along the Belt and Road initiative to achieve win-win result for both parties and even multiple parties? This paper combs the long-term development strategies of the five Central Asian countries-Kazakhstan, Kyrgyzstan, Tajikistan,
Turkmenistan and Uzbekistan in detail, and combines them with the country-specific plan conducted by China for fulfilling the promises of the Belt and Road initiative, which will help us understand the reason why the Belt and Road Initiative has gained widely support from the countries.

\section{THE LONG-TERM DEVELOPMENT STRATEGIES OF THE FIVE CENTRAL ASIAN COUNTRIES AND THE COMPLEMENTARITY OF THE BELT AND ROAD INITIATIVE}

2.1 Kazakhstan's long-term development plans and key development areas

Kazakhstan-2030 issued by the President of Kazakhstan, Nazarbayev proposed a grand blueprint 'to be one of the top 50 countries in the world by 2030' for Kazakhstan's social and economic development. The development strategy is divided into 3 stages for the above purpose, and focused on the improvement of the following five key areas: (1) national security and social stability; (2) high-level foreign investment; (3) national health, education and welfare; (4) energy resources; (5) infrastructure construction. At the beginning of the planning and design, Kazakhstan took into account the 30-year active cycle of a generation, especially the iterative factors of the country's resource stock and new energy expected 30 years later. The first long-term plan set the time node in 2030. However, due to the outbreak of the financial crisis in 2008, Kazakhstan is expected to misjudge the economic cycle in its long-term planning, and the unexpected financial crisis will bring new challenges to Kazakhstan's economic development. Planning cannot effectively guide the country's long-term economic development. Under this circumstance, in 2013, Kazakhstan drafted Kazakhstan-2050, which made major adjustments to the original State of the Union address. In addition to some strategic objectives, the original five areas of emphasis were adjusted significantly in details. In order to give more information about the needs of Kazakhstan and the relationship between Kazakhstan and China, Table 1 give more details about projects signed by these two nations after 2000 . 
Table 1: Summary of important bilateral agreements between China and Kazakhstan

\begin{tabular}{|c|c|}
\hline Country & Specific Agreement (year) \\
\hline Kazakhstan & 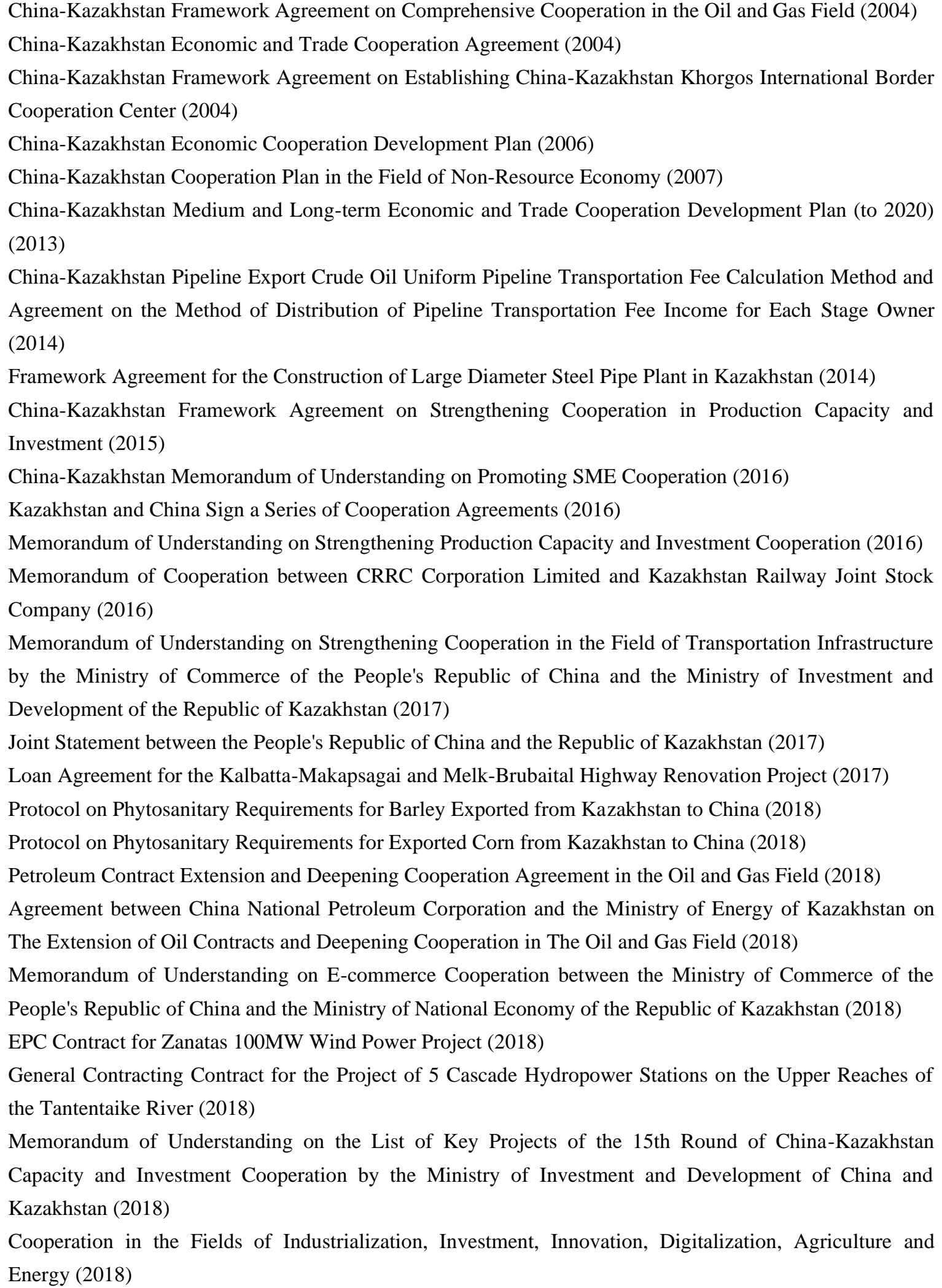 \\
\hline
\end{tabular}


2.2 Kyrgyzstan's long-term development plan and key development areas

Prior to 2010, Kyrgyzstan's Country Development Strategy (CDS) mainly emphasized through sustainable economic development, job creation, high sustainable income, high universality of social services, and high quality in a healthy, higher standard of living with friendly environment and the improvement of people's living standards. Key development areas include energy, minerals, agriculture, processing, construction, tourism, transportation infrastructure, telecommunications, and technological innovation and development. In early December 2012, President Atambayev of Kyrgyzstan announced the Kyrgyzstan 2013-2017 Development Strategy (KDS) at the first conference of the National Council for Stable Economic Development, which is the five-year plan for economic development, aiming to attract domestic and foreign investors to the greatest extent, with special emphasis on support for minerals, energy, tourism, agriculture, transportation, finance, and environmentally friendly technologies. The agricultural industry, energy, mining, transportation and communications, tourism and service industries are regarded as strategic sectors that promote economic development. In October 2017, the newly-appointed Kyrgyz President Sorumby Zhenbekov drafted the latest long-term development plan-Sustainable Development Strategy 2018-2040 (hereinafter Kyrgyzstan 2040). The plan took 2017-2023 as the first stage, clarifying the goals, scope of government work, special tasks and projects for the next five years, and regards political stability as a guarantee for achieving long-term strategic goals. The main goal of Kyrgyzstan 2040 emphasized the establishment of a peaceful and prosperous Kyrgyzstan for the people. In terms of economy, Kyrgyzstan hoped to improve the economic welfare of the people by providing decent jobs and stable income. Specifically, it included creating high-productivity jobs, decent jobs, stable incomes, and increasing the export potential of labor-intensive jobs, and help governments to transform from the status of an absolute service provider to the status of a manager by issuing policies, standards and work frameworks, etc., and provide individuals with more personal training and protect the rights of consumers, specifically by improving the national health and education level, more accessible and high-quality medical insurance system, popularizing high-quality educational opportunities, etc. All these actions are regarded as the main driving force for social development. In terms of national security, Kyrgyzstan aimed to create a safe and stable social environment for every citizen, so that citizens can live in a peaceful and secure environment, and the rights and freedoms ensured include the construction of Reliable laws and methods for enforcing the environment, protecting nature, environmental resources, etc. serve as the stability of Kyrgyzstan's society and environmental security. To sum up, the sectors of agriculture, light industry, agro-processing industry, and tourism, which provide the most jobs in Kyrgyzstan, have become the key of sustainable development of the national economy. In order to give more information about the needs of Kyrgyzstan and the relationship between Kyrgyzstan and China, Table 2 give more details about projects signed by these two nations after 2000 .

Table 2: Summary of important bilateral agreements between China and Kyrgyzstan

\begin{tabular}{|c|c|}
\hline Country & Specific Agreement (year) \\
\hline \multirow{10}{*}{ Kyrgyzstan } & China-Kyrgyzstan Energy Cooperation Agreement (2000) \\
\hline & China-Kyrgyzstan Agreement for Avoiding Double Taxing (2000) \\
\hline & China-Kyrgyzstan Cooperation Program from 2004 to 2014 (2004) \\
\hline & China Banking Regulatory Commission and the State Banking Regulatory Cooperation Agreement \\
\hline & The Cooperation Plan of the Ministry of Foreign Affairs of China and Kyrgyzstan in 2007 (2006) \\
\hline & Joint Declaration of the People's Republic of China and the Kyrgyz Republic on the Establishment of \\
\hline & Strategic Partnership (2013) \\
\hline & Joint Declaration of the People's Republic of China and the Kyrgyz Republic on Further Deepening \\
\hline & the Strategic Partnership (2014) \\
\hline & Strategic Cooperation Agreement between Yanqi County and the Kyrgyz Republic to Build the Silk \\
\hline
\end{tabular}




\begin{tabular}{|l|l|}
\hline Road Economic Belt (2014) \\
China-Kyrgyzstan RMB Currency Swap Agreement (2015) \\
China-Kyrgyzstan Cooperation Framework Agreement on Bilateral Economic and Technical \\
Assistance Projects (2015) \\
Investment Agreement between the Kyrgyz Government and the China-Kyrgyzstan Gas Pipeline \\
Company (2015) \\
Contract for the Survey and Design of Kyrgyzstan's 50 MW Balekchi Wind Farm (2017) \\
$\begin{array}{l}\text { The Asia Star Agricultural Industry Cooperation Zone Signs a Memorandum of Understanding on } \\
\text { Economic and Trade Cooperation (2017) } \\
\text { Memorandum of the Ministry of Commerce of the People's Republic of China and the Investment } \\
\text { Cooperation Zones (2018) } \\
\text { CNAS-KAC Accreditation Cooperation Memorandum of Understanding (2018) }\end{array}$ \\
\hline
\end{tabular}

2.3 Tajikistan's long-term development plan and key development areas

In 2005, to provide an ideal platform for the country's further development, the Presidential Palace of Tajikistan drafted the National Development Strategy (NDS) to ensure the country's long-term and orderly development and match the country's Millennium Development Goals (MDGs). All regions, departments, and regional conceptual frameworks, policies, projects, plans, and activities of all government agencies related to national development are carried out under the contents of the NDS. Combining this plan with the requirements of the national Poverty Reduction Policy, Tajikistan will focus on three areas between 2007 and 2015. They are:(1) reform the administrative department, establish more transparent, clear-cut powers and responsibilities, and Anti-corruption government; (2) through a freer economic environment, strengthen property rights and legal efficiency, and adopt Public-Private Partnership to develop the private sector and attract investment; (3) effectively tap the potential of human resources in improving the quantity and quality of social services for the poor and provide the masses with great opportunities to participate into the process of social construction and strengthen social cooperation to achieve the Millennium Development Goals.
On December 1, 2016, the Parliament of Tajikistan approved the National Development Strategy 2030 (hereinafter Tajikistan 2030). Combining the Tajikistan 2030 with the Sustainable Development Goals (SDGs) of Tajikistan at the 70th United Nations General Assembly in 2015, Tajikistan's work centers in the next 15 years are: (1) education; (2) health; (3) employment; (4) reducing inequality, fighting corruption; (5) food safety and nutrition; (6) competent government; (7) social welfare; (8) prevention of potential conflicts; (9) Energy security, environmental protection, and (10) population management. The Tajikistan government will prevent or reduce economic vulnerabilities and enhance industrialization and efficiency of energy use. Moreover, it promised to provide a better environment for innovation or integrate new technologies into the development of society and economy. The Tajikistan 2030 combined with the 10 work centers, will ultimately achieve the five ultimate goals of ensuring energy security, achieving economic transformation, ensuring food safety and high-level national health, and expanding employment. In order to give more information about the needs of Tajikistan and the relationship between Tajikistan and China, Table 3 give more details about projects signed by these two nations after 2000 . 
Table 3: Summary of important bilateral agreements between China and Tajikistan

\begin{tabular}{|c|c|}
\hline Country & Specific Agreement (year) \\
\hline Tajikistan & 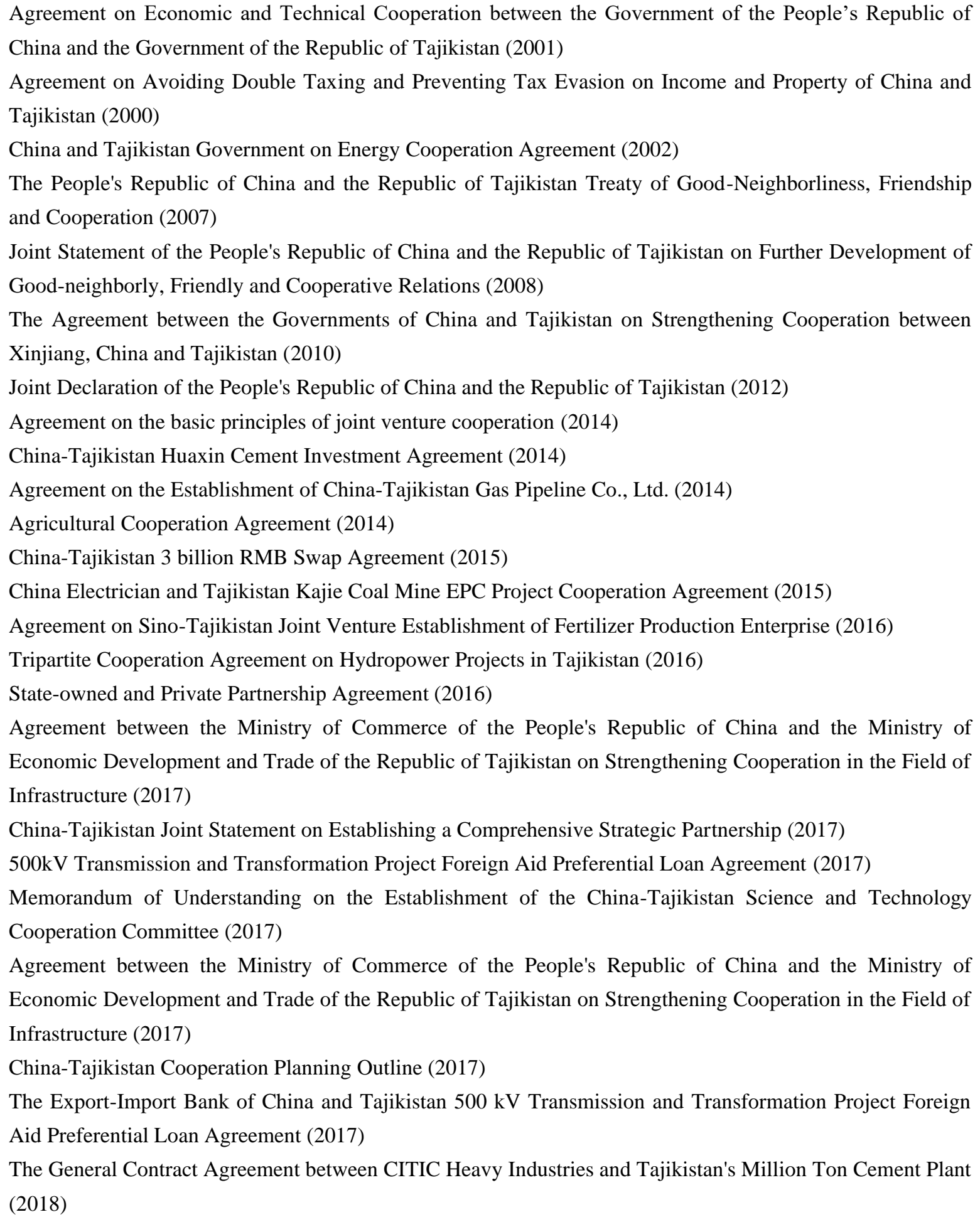 \\
\hline
\end{tabular}

2.4 Turkmenistan's long-term development plan and key development areas

Turkmenistan promulgated the Political, Economic and Cultural Development Strategy of Turkmenistan to 2020 (hereinafter Turkmenistan Strategy) in order to achieve the economic development level, living standard and social security of developed countries. In addition, Turkmenistan Strategy will continue to increase GDP per capita and increase the investment environment and attractiveness, which together constituted the center of 
long-term development at this stage. In addition, Turkmenistan Strategy regarded the development of the nine economic sectors of the oil and natural gas industry, the chemical industry, the textile industry, the building materials industry, agriculture, transportation, communications, and the social sector, as the cornerstone of achieving goals. However, the financial crisis exposed the fragility of Turkmenistan's economy-product production was too concentrated in certain places and the consumption market was single. Therefore, after 2008, a key to the country's policy was to achieve economic diversification. Increasing investment in infrastructure, especially in inter-provincial and remote areas, had become the key to economic diversification. In addition, the improvement of monetary and credit policies and the banking system are important supplements to ensure the realization of Turkmenistan's various tasks. In August 2016, Turkmenistan released the latest national long-term development plan-Turkmenistan's National Social and Economic Development Plan from 2018 to 2024. This plan further emphasized the importance of knowledge and innovation, and the diversification of sectors. In order to give more information about the needs of Turkmenistan and the relationship between Turkmenistan and China, Table 4 give more details about projects signed by these two nations after 2000.

Table 4: Summary of important bilateral agreements between China and Turkmenistan

\begin{tabular}{|c|c|}
\hline Country & Specific Agreement (year) \\
\hline Turkmenistan & 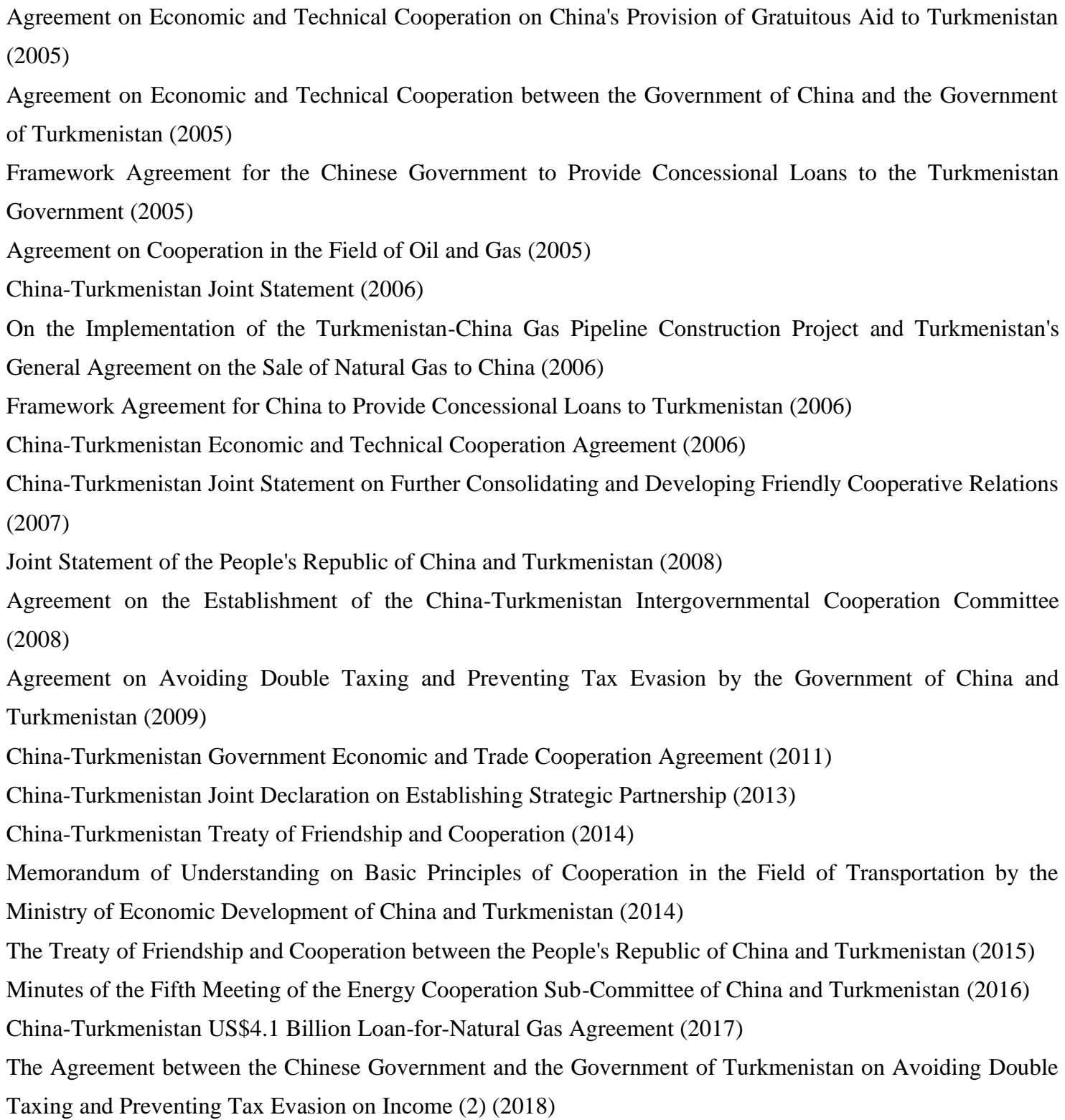 \\
\hline
\end{tabular}


2.5 Uzbekistan's long-term development plan and key development areas

An earlier long-term economic plan of Uzbekistan was called Building the Future: Uzbekistan's Unique Market Economy Transformation Road (hereinafter UUMETR), which was proposed by the President of Uzbekistan in 1993. The UUMETR emphasized the investment of domestic resources and foreign capital in limited sectors to realize the transformation and upgrading of economic structure. Although the 2008 financial crisis swept the global economy, compared with Uzbekistan's neighbors, conservative macroeconomic management policies had protected Uzbekistan from greater negative shocks. In general, Uzbekistan's overall public policy experienced a major turning point only in 2007. Therefore, the last important national priority areas in 2006 were taken as the representative of the early long-term policies. In February 2017, Uzbekistan approved the 2017-2021 new five-year plan. In addition to improving existing problems, Uzbekistan further provided explanations and future solutions for all aspects of social and economic issues. In terms of economic development, Uzbekistan will focus on five areas: departments, legal systems, economic development, social progress, and national security. Among them, the overall requirements of the economic sector include basically strengthening macro-stability and maintaining high economic growth rates, enhancing economic competitiveness through deepening economic structural reforms and diversifying pillar industries, modernizing and strengthening agricultural sector development, deepening institutional and structural reforms, and reducing government intervenes, and introducing stricter policies to protect intellectual property rights and private property rights. Moreover, Uzbekistan still emphasized the development of transportation and communication infrastructure, development and utilization of renewable energy, tourism, agriculture and light industry. In order to give more information about the needs of Uzbekistan and the relationship between Uzbekistan and China, Table 5 give more details about projects signed by these two nations after 2000.

Table 5: Summary of important bilateral agreements between China and Uzbekistan

\begin{tabular}{|c|c|}
\hline Country & Specific Agreement (year) \\
\hline Uzbekistan & $\begin{array}{l}\text { China-Uzbekistan Joint Statement on Further Developing and Deepening the Friendly and Cooperative } \\
\text { Partnership (2004) } \\
\text { China-Uzbekistan Government Economic and Technical Cooperation Agreement (2004) } \\
\text { Framework Agreement for the Government of the People's Republic of China to Provide Concessional } \\
\text { Loans to the Government of the Republic of Uzbekistan (2004) } \\
\text { Memorandum of Understanding on Expanding Economic, Trade, Investment and Financial } \\
\text { Cooperation between the Governments of China and Uzbekistan (2004) } \\
\text { China-Uzbekistan Friendship and Cooperation Partnership Treaty (2005) } \\
\text { China-Uzbekistan Agreement on Mutual Customs Assistance (2005) } \\
\text { China-Uzbekistan Government Joint Communiqué (2007) } \\
\text { China-Uzbekistan Governmental Non-Resource and High-tech Cooperation Plan (2010) } \\
\text { Framework Agreement on Natural Gas Purchase and Sale (2010) } \\
\text { Memorandum of Understanding on Expanding Cooperation between the Chinese and the Government } \\
\text { of Uzbekistan in the Field of Natural Gas (2010) } \\
\text { Agreement on the Establishment of an Intergovernmental Cooperation Committee (2011) } \\
\text { Decision on Approving the Treaty of Amity and Cooperation between China and Uzbekistan (2014) } \\
\text { China-Uzbekistan Gas Pipeline D Line Inter-Enterprise Agreement (2014) } \\
\text { Muballek Natural Gas Chemical Plant Cooperation Memorandum (2014) } \\
\text { Joint Declaration of the People's Republic of China and the Republic of Uzbekistan (2014) } \\
\text { China-Uzbekistan Economic and Technical Cooperation Agreement Bank Account Handling Rules } \\
\text { (2015) }\end{array}$ \\
\hline
\end{tabular}




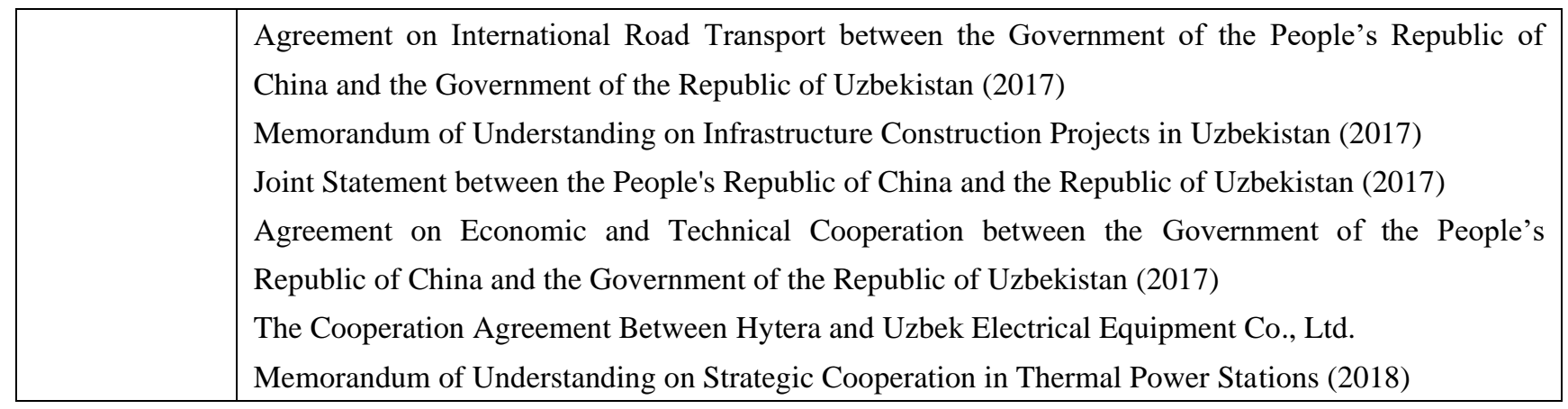

\section{STRATEGIC DOCKING OF PRODUCTION} CAPACITY COOPERATION UNDER CHINA'S ONE BELT ONE ROAD

\section{INITIATIVE}

3.1 Policy docking under the Belt and Road Initiative

\subsection{Belt and Road Initiative}

The Belt and Road Initiative itself provides strong cooperation basis for China and the Central Asian countries. The Belt and Road Initiative was proposed by China's President Xi Jinping in 2013. He mentioned that the five Central Asian countries are currently facing very similar problems: these countries lack sufficient self-owned funds, technology, professionals and infrastructure. However, huge geographical advantages, energy advantages and labor advantages are also outstanding. These conditions provide strong cooperation basis for China and the five Central Asian countries. The Belt and Road initiative is based on the principles of mutual consultation, construction and sharing. It aims to promote economic globalization and cultural diversification, and helps countries realize interconnection and inclusiveness, mutual learning and mutual benefit. Starting from China's own development experience, it contributes Chinese wisdom to solve world development problems and becomes maintenance and advancement. The Belt and Road initiative provides countries along the route with unparalleled development experience of China. As the largest developing country and the second largest economy in the world, China has strong and highly cost-effective infrastructure construction capabilities. Moreover, the technological accumulation of renewable energy such as photovoltaic energy, hydropower, and electric energy is fully in line with the needs of the long-term development of the Central Asia countries. In terms of industrial capacities, and the rapid and stable economic development provides China with stable and excellent capacity output strength, which is in line with the current needs of the five Central Asian countries.

3.12 Long-term plans in China: Made in China 2025 and Guidelines on Promoting International Cooperation in Capacity and Equipment Manufacturing

The Guidelines on Promoting International Cooperation in Capacity and Equipment Manufacturing (hereinafter Guidelines) emphasizes accelerating the pace of international co-operation in railway construction, vigorously developing overseas electricity power projects and improving the level of international cooperation in the light industry and textile industry, improving international competitiveness of communication industry, promoting the export of construction machinery and other manufacturing industries to cover more the global business network, etc., which almost completely meets the technology and resource needs of the five Central Asian countries in terms of infrastructure construction, industry, agriculture and energy exploitation, etc. Moreover, the long-term plan Made in China 2025 also reflects China's determination to become a strong manufacturing country in the future. The ten major areas and five major projects (Table 6) emphasized are also a strong guarantee for countries' long-term cooperation in these fields with China. Briefly, the Guidelines provide a policy basis for the current capacity cooperation between China and the five Central Asian countries, while the Made in China 2025 guarantees the long-term benefits of cooperation with China in related fields. 
Table 6: Ten key areas and five major projects of Made in China 2025

\begin{tabular}{|c|c|}
\hline Ten key areas & Five major projects \\
\hline 1.Information Technology Industry & \multirow{2}{*}{$\begin{array}{l}\text { 1. Manufacturing Innovation Center Construction } \\
\text { Project }\end{array}$} \\
\hline 2. Advanced CNC Machine Tools and Robots & \\
\hline 3. Aerospace Equipment & \multirow{2}{*}{ 2. Intelligent Manufacturing Engineering } \\
\hline 4. Marine Engineering Equipment and High-Tech Ships & \\
\hline 5. Advanced Rail Transit Equipment & \multirow{2}{*}{ 3. Projects on Strengthening Basic Industries } \\
\hline 6. Energy Saving and New Energy Vehicles & \\
\hline 7. Electricity power equipment & \multirow{2}{*}{ 4. Green Manufacturing Engineering } \\
\hline 8. Agricultural Equipment & \\
\hline 9. New Materials & \multirow[b]{2}{*}{ 5. Advanced Equipment Innovation Project } \\
\hline $\begin{array}{l}\text { 10.Biomedicine and High-Performance Medical } \\
\text { Equipment }\end{array}$ & \\
\hline
\end{tabular}

Source: Autor's collection from Made in China 2025 and Guidelines on Promoting International Cooperation in Capacity and Equipment Manufacturing

3.2 Supplementary Policies for China-Central Asia Capacity Cooperation

China has also established a multi-dimensional cooperation guarantee mechanism in promoting the Belt and Road Initiative. The 13th Five-Year Plan for Economic and Social Development of the People's Republic of China (the 13th Five-Year Plan) listed the Belt and Road Initiative as core content and main tasks, which is a symbol the basic perfection of the top-level design and planning in national level. Since then, the Belt and Road Initiative has interpreted the essence of win-win with the Five Connectivity: (1) policy connectivity;(2) infrastructure connectivity;(3) trade connectivity;(4) finance connectivity; (5) people connectivity.

Policy connectivity. The Regional Comprehensive Economic Partnership Agreement (RCEP), the Rome Declaration and other cross-regional bilateral policy consensus have laid the foundation for political, economic and trade mutual trust at the macro level for countries and regions joining in the Belt and Road Initiative. Under the guidance of these macro policies, China and the countries related to the Belt and Road Initiative signed cooperation, memorandums of understanding, and multi-country joint statements such as China-Japan-Thailand Trilateral Cooperation in the Eastern Economic Corridor of Thailand, Lanmen-Mekong Cooperation, China-Pakistan Economic Corridor (CPEC), the Dushanbe Declaration, the Joint Statement on E-commerce between China and the 75
WTO countries and so on to reach cooperation consensus. On the premise of adhering to mutual benefit and win-win results, using the Belt and Road Initiative to realize the organic connection of bilateral and multinational economic and trade cooperation, to further promote the establishment of political mutual trust and strategic partnerships. Emphasizing on complementary advantages and achieve win-win economics and trade is the essence of the Belt and Road.

Infrastructure connectivity. China attaches great importance to the standards for road construction in the Belt and Road Initiative. The Belt and Road Transport Alliance established in 2016 paid particular attention to exchanges and cooperation with Central Asian countries in the field of road construction. In 2017, the 13th National Development and Reform Commission included 13 Various departments and units have jointly established the Belt and Road Initiative Public-Private Partnership (PPP) working mechanism to strengthen cooperation with countries involved in the Belt and Road Initiative in the field of infrastructure construction and to actively promote the PPP model to achieve proper and rapid implementation of infrastructure projects in those countries. Since most of the road infrastructure in Central Asian countries uniformly used the standards of the former Soviet Union, after the collapse of the Soviet Union, the Central Asian countries were unable to repair and maintain the existing road system. Due to problems such as inefficient 
supervision and rent-seeking corruption, coupled with long cycles in road investment, transit roads usually pass through remote and rural areas, which are typical low-return, high-risk projects, especially that the five Central Asian countries are typical inland country which always has very complex terrain. Therefore, in the field of infrastructure connectivity, China's infrastructure construction has actually helped Central Asian countries to narrow the development gap between regions. Through PPP, BOT, etc., the main benefits in the future will definitely be transferred to the cooperative countries. The concept of infrastructure connectivity has undoubtedly greatly compensated for the crux of the resource allocation of Central Asian countries, enabling these countries to locate limited resources in the economic development and balance regional development.

Trade connectivity. Economic and trade cooperation is one of the key contents of the Belt and Road Initiative, and its foundation and leading role have injected strong impetus into the realization of the Five Connectivity. China has implemented many measures in order to ensure the smooth flow of trade, universities, win-win and development. First, building a fair multilateral trading platform. Through the establishment of platforms such as China-ASEAN Expo, China-South Asia Expo, China-CEEC Investment and Trade Expo, China-Asia-Europe Expo, Canton Fair, and China International Import Expo, China has continued to reduce trade barriers, improve policies to promote imports and exports, achieve economic complementarity, and maximize economic and trade potential. Second, promoting free trade agreement negotiations. Speeding up the construction of free trade zones with countries with Central Asian countries is an important measure to promote trade facilitation with the Belt and Road Initiative countries and to deepen economic and trade cooperation on a larger scale and at a higher level. Third, building economic and trade industrial cooperation zones. Overseas economic and trade cooperation zones have always been an important carrier for China to promote international cooperation in production capacity and equipment manufacturing and are an important part of China's adherence to the principle of openness and transparency as well as the promotion of trade liberalization. Finally, help countries related to the Belt and Road Initiative to strengthen capacity building. China is an important participant in the United Nations 2030 Agenda for Sustainable Development so that it will provide a large number of research and training places domestically and send senior economic and trade experts to support trade and investment promotion arrangements proposed by the WTO and the United Nations. Although China and the five Central Asian countries have not signed a free trade agreement, the success of the China-Kazakhstan Khorgos-Gate of the East Special Economic Zone and China's continuous efforts to promote the establishment and construction of the China-Central Asian Free Trade Zone will further guarantee the implementation of the concept of trade connectivity between China and Central Asia.

Finance connectivity. The shortage of funds is a major obstacle for Central Asian countries to achieve long-term planning. In addition to government-level cooperation and assistance, China has also established a more complete mechanism to increase mutual trust in politics and economy. At the end of 2014, the China Administration of Foreign Exchange, China Investment Corporation and other departments and units jointly funded the establishment of the Silk Road Fund, with the first phase of registered capital reaching 10 billion US dollars. To end of 2016, the China Development Bank had loaned more than US\$1,100 to countries involved in the Road and Belt Initiative, supporting over 600 projects. At the same time, 603 capacity improvement and equipment manufacturing projects are funded by the Export-Import Bank. ICBC established 123 branches in 18 countries involved in the Road and Belt Initiative and provided those countries more than 22 billion US dollars loans. In addition, the establishment and mechanism of the Asian Infrastructure Investment Bank (AIIB) meets the capital and institutional requirements for the bilateral cooperation. AIIB is a government multilateral development institution with a capital scale of US\$100 billion. At present, the number of member countries has increased to more than 70 , surpassing the membership of the Asian Development Bank (ADB). While providing funds for infrastructure construction in Asia, the multinational board of directors has well protected the legal rights of member states, and 
the institutional arrangements have effectively reduced moral and economic risks. Since the use of funds meets the demands of member states and is driven by China's interests, the establishment of AIIB has effectively responded to the misinterpreted Chinese interest theory in the West. AIIB has used its own actions to prove that the AIIB is not China's AIIB. At present, except Turkmenistan, all other Central Asian countries are the members of AIIB. To the end of 2017, AIIB's total investment reached 7.5 billion U.S. dollars, with a total of 1.73 billion U.S. dollars in loans and 35 projects were approved. The two projects passed in Central Asia are both in Tajikistan and are energy and transportation projects. In contract, only one project in China has been approved.

People connectivity. The friendship between the nations lies in the closeness of the people, and the closeness of the people lies in the communication of hearts. People's hearts are the biggest political and most fundamental basis for cooperation. The misinterpretation of the Belt and Road Initiative by the Western media tends to incite the people and create pressure on public opinion. This proves that the ultimate vision of the Belt and Road Initiative determines that it cannot fulfill without the long-term support of average people. The cause of people connectivity aims to build up the spirit of ownership of all parties and promote the development of relationships. It is an important practice for building a community with a shared future for mankind. On the cultural level, China has established Confucius Institutes in Central Asia, co-hosted cultural year activities, and provided government scholarships to study in China. In humanitarian aspects, Chinese governments has provided more than 2 billion RMB in emergency food aid and donated 1 billion US dollars to the South-South Cooperation Assistance Fund and provided 1 billion US dollars in aid to relevant international organizations, benefiting countries in many important fields such as food, daily use, medical care, and education. In addition to activities in the fields of culture and education, China also provided assistance to the Central Asian countries in the fields of military, infrastructure construction, and people's livelihood (Table 7). Action to implement the Belt and Road Initiative not only requires economic cooperation, but also requires sincere exchanges and people's resonance to provide the most solid foundation for promoting economic and trade cooperation between China and Central Asian countries.

Table 7: Incomplete statistics of China's aid to the five Central Asian countries

\begin{tabular}{|c|c|}
\hline Country & Content \\
\hline 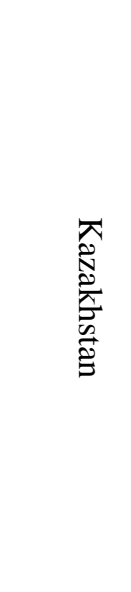 & $\begin{array}{l}\text { In 2013, China assisted Kazakhstan in building the Eurasian Canal; } \\
\text { In 2014, China Meteorological Administration provided technical assistance to Kazakhstan; } \\
\text { In 2015, the Health and Family Planning Commission of ShanXi Province and Kazakhstan signed a framework } \\
\text { agreement to assist in the construction of the ShanXi Village hospital; } \\
\text { In 2015, China provided Kazakhstan with free military technical assistance for tractors and loading platforms; } \\
\text { In 2016, China National Petroleum Corporation completed the construction of the Astana National Dance } \\
\text { Academy and Ballet Theater in Kazakhstan; } \\
\text { In } 2017 \text {, China-Kazakhstan completed the handover of the } 1 \text { MW solar power plant and the } 5 \text { MW wind power } \\
\text { plant aided by China; } \\
\text { In } 2018 \text {, China completed the aid construction of the Kazakh Junior Military Academy's electronic classroom; } \\
\text { To the end of } 2017 \text {, China had provided US } \$ 43 \text { billion in aid to Kazakhstan. }\end{array}$ \\
\hline 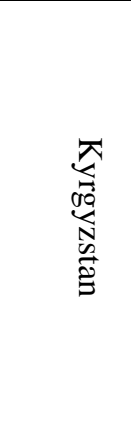 & $\begin{array}{l}\text { In 2013, China assisted Kyrgyzstan in the construction of the Issyk-Kul road restoration project; } \\
\text { In 2014, China provided Kyrgyzstan with US\$16 million in military assistance; } \\
\text { In 2014, China completed the aid construction of the new medical building project of the Kyrgyz National } \\
\text { Hospital; } \\
\text { In 2015, the foreign aid project China-Kyrgyzstan Modern Agricultural Technology Joint Research and } \\
\text { Demonstration Center was approved by the Ministry of Science and Technology; } \\
\text { In 2015, China completed the aid of } 267 \text { tractors in Kyrgyzstan; } \\
\text { In 2017, China aided the construction of Osh Hospital in Kyrgyzstan; }\end{array}$ \\
\hline
\end{tabular}




\begin{tabular}{|c|c|}
\hline & $\begin{array}{l}\text { In 2018, China assisted in the construction of the asphalt pavement restoration project in the capital of } \\
\text { Kyrgyzstan; } \\
\text { In 2018, China assisted Kyrgyzstan's irrigation system renovation project; } \\
\text { In 2019, China assisted Kyrgyzstan with } 30 \text { tons of rice, } 20 \text { tons of soybeans, } 10 \text { tons of corn, } 5 \text { tons of beef, } \\
\text { RMB } 2 \text { billion of interest-free loans and five years of free railway-related technical support. }\end{array}$ \\
\hline & $\begin{array}{l}\text { In 2013, China assisted in the construction of the Yawan-Wahdat railway project in Tajikistan; } \\
\text { In 2013, China assisted Tajikistan with } 20 \text { million RMB of police supplies; } \\
\text { In 2015, China provided } 10 \text { million RMB in material assistance to Tajikistan; } \\
\text { In 2016, China assisted in the construction of four border checkpoints and a military training center in } \\
\text { Tajikistan; } \\
\text { In 2016, China completed the construction assistance project of the office building of the Tajikistan } \\
\text { Anti-Narcotic Branch Office; } \\
\text { In 2016, China completed the construction of two schools in Vakhdat City and Rudaki Region; } \\
\text { In 2016, China completed the Dushanbe No. } 2 \text { thermal power station aid project; } \\
\text { In 2018, China completed the aid construction of road restoration projects in Kurganqiube and Kulyab cities in } \\
\text { Takhatlon Prefecture; } \\
\text { In 2018, China provided US } 66 \text { billion in assistance for the construction of the 400-capable gas pipeline in } \\
\text { Tajikistan for the Central Asia-China Gas Pipeline; } \\
\text { In 2018, China assisted in the construction of } 3 \text { schools in Tajikistan; } \\
\text { In 2018, China helped build the Tajikistan government parliament complex with } 1.5 \text { billion RMB free of charge. }\end{array}$ \\
\hline & $\begin{array}{l}\text { In 2013, China South Locomotive Co., Ltd. assisted Turkmenistan passenger locomotive and accessories; } \\
\text { In 2013, Migan Village Water Plant Project, a component of China Natural Gas Transportation Corporation; } \\
\text { In 2014, China initiated a telecommunications completion project for components in Turkmenistan. }\end{array}$ \\
\hline & $\begin{array}{l}\text { In 2013, China provided Uzbekistan Customs with a US } \$ 4.4 \text { million mobile inspection and inspection } \\
\text { equipment; } \\
\text { In 2015, China Railway Tunnel funded rural schools in Uzbekistan; } \\
\text { In 2015, China Shanghai Pharmaceuticals assisted Uzbekistan with } 80 \text { million RMB in medical equipment; } \\
\text { In 2015, China completed the assistance of the new electrified railway project in the Malakand to Karshi section } \\
\text { of Uzbekistan's national railway; } \\
\text { In 2016, China assisted the restoration project of historical and cultural relics in Kwarazmian Prefecture, } \\
\text { Uzbekistan; } \\
\text { In 2017, China assisted Uzbekistan's Hydrometeorological Administration to provide meteorological-related } \\
\text { technologies and equipment; } \\
\text { In 2017, China's Huawei assisted in the construction of the Smart Classroom project of } 59 \text { Middle School in } \\
\text { Tashkent, Uzbekistan; } \\
\text { In 2017, China completed the aid project for the Uzbekistan dredger; } \\
\text { In 2018, China completed the aid project for teaching equipment in Uzbekistan; } \\
\text { In 2018, China completed assistance to the Uzbekistan Children's Medical Center and the Tashkent Children's } \\
\text { Hospital for medical equipment projects; } \\
\text { In 2018, China funded Uzbekistan's water supply project (TA-9481 UZB). }\end{array}$ \\
\hline
\end{tabular}

\section{CONCLUSION}

The success of China's cooperation with the five countries in Central Asia is not accidental. With the help of top-level strategies and various safeguards, bilateral interests have been greatly protected. In addition, because China often uses Public-Private Partnership and other 
methods to participate in the construction of the host country and provide diversified preferential loans, the host country's doubts about China's penetration have been relieved. Judging from the cooperation experience of China and the five Central Asian countries, this article finds that the following points may be the reasons why China has achieved great achievements with the countries participating in the Belt and Road Initiative:

1. Complementary strategies. Before China and the five Central Asian countries reached capacity cooperation, they had a good relationship foundation. They established diplomatic relations with the five Central Asian countries for more than 25 years. Both sides have understood each other's strategic needs from previous cooperation. Therefore, by combining the national macro-level development strategy and the country-specific strategy, China and the five Central Asian countries have achieved complementarity from the development strategy level. This complementarity is not deliberate, but the inevitability of the different development stages of the two groups. Therefore, the top-level design and difference in the development stage determine that the cooperation between the five Central Asian countries and China is more balanced and more cost-effective compared to cooperation with advanced countries in many aspects.

2. Safeguard measures. In addition to the bilateral cooperation between China and the five Central Asian countries, the multilateral international institutions that the five Central Asian countries participate in can provide additional guarantees for the cooperation between the five Central Asian countries and China. For example, the AIIB and ADB mentioned in Finance Connectivity can greatly protect the rights and interests of relatively disadvantaged countries. These institutions can also protect the resources and security of Central Asian countries from being plundered.

3.Nothing about geopolitics. China's participation in the cooperation of the five Central Asian countries does not design political and geopolitical goals, although the increase in economic influence will inevitably bring political and geopolitical influence. However, from top-level design to specific strategic planning, there is not much military cooperation between China and the five Central Asian countries, and there has never been a tendency to participate in geopolitical conflicts for China and no actual conflict cases involving China.

4. Central Asian country will finally control all the projects. The cooperation between China and the five Central Asian countries usually adopts Public-Private Partnership, BOT and other similar cooperation methods, which ensures that the infrastructure and other similar assets within the projects are owned by Central Asian countries.Therefore, there is no need to worry about China's influence on Central Asian countries by controlling infrastructure, basic energy supply, etc. In this process, there will inevitably be technical, financial, and training support and Central Asian countries can not only improve their material base, but also achieve breakthroughs in their own technologies through the cooperation with China.

\section{REFERENCES}

[1] Azamat S. Sulimanov. "Geopolitical interests of China in Central Asia". (2018):145-149.

[2] Bin Hu. "Oil and gas cooperation between China and Central Asia in an environment of political and resource competition". 11.4(2014):596-605.

[3] Fang MA, Baocheng FAN, and Guanglu MENG."Research on Common Development Mechanism between China and The Five Countries of Central Asia under The Belt and Road Framework".Proceedings of the 6th Academic Conference of Geology Resource Management and Sustainable Development.Ed.. Aussino Academic Publishing House (2018):548-557.

[4] Gulinaer-Yusufu."Research on Energy Cooperation Strategy between China and Central Asia Based on Xinjiang".Proceedings of 2018 2nd International Conference on Social Sciences, Arts and Humanities (SSAH 2018).Ed.. Francis Academic Press, 2018, 361-364

[5] Hongzhu Li."Energy Cooperation between China and Central Asia from the Perspective of Geopolitics: Challenges and Countermeasures". Proceedings of 2018 International Conference on Educational Research, Economics, Management and Social Sciences(EREMS 2018).Ed.. Francis Academic Press,UK, 2018, 162-165.

[6] Jin Wang and Dehang Kong. "Counter-Terrorism Cooperation Between China and Central Asian States in the Shanghai Cooperation Organization". 5.1(2019):15.

[7] Karen Smith Stegen. "Understanding China's global energy 
strategy". 10.2(2015):194-208.

[8] Qin Qi et al. "A Study on the Spatial Distribution of China's Potential Foreign Cooperation on Grain from Geographical View". 9.6(2018):585-591.

[9] Qurbonboyev Javohir Mominjonogli. "About international economic and social relations between Uzbekistan and China". 10.5(2020):1333-1337.

[10] Timur Dadabaev. "Transcontinental Silk Road Strategies:Comparing China, Japan and South Korea in Uzbekistan". (2019)

[11] Yakov Silin et al. "The silk road economic belt: balance of interests". 6.3(2018):293-318.

[12] Ying Zhang."A Study on Trade and Investment Facilitation in Central Asia".Results of 2016 International Conference on Management Science and Innovation (Management Science and Innovation Volume I).Ed.. China Scientific Research Publishing, 2016, 198-203.

[13] Zahid Khan and Guo Changgang and Muhammad Afzaal. "China-Pakistan Economic Corridor at the Cross Intersection of China, Central Asia and South Asia: Opportunities for Regional Economic Growth". 53.2(2020):200-215.

[14] Zhou Qiang and He Ze and Yang Yu. "Energy geopolitics in Central Asia: China's involvement and responses". (2020):1871-1895. 